IZA DP No. 7217

On the Power of Childhood Impressions for Skill Formation: Initial Evidence and Unsettled Questions

Friedhelm Pfeiffer

February 2013 


\title{
On the Power of Childhood Impressions for Skill Formation: Initial Evidence and Unsettled Questions
}

\author{
Friedhelm Pfeiffer \\ Centre for European Economic Research (ZEW), \\ University of Mannheim and IZA
}

Discussion Paper No. 7217

February 2013

\author{
IZA \\ P.O. Box 7240 \\ 53072 Bonn \\ Germany \\ Phone: +49-228-3894-0 \\ Fax: +49-228-3894-180 \\ E-mail: iza@iza.org
}

\begin{abstract}
Any opinions expressed here are those of the author(s) and not those of IZA. Research published in this series may include views on policy, but the institute itself takes no institutional policy positions. The IZA research network is committed to the IZA Guiding Principles of Research Integrity.

The Institute for the Study of Labor (IZA) in Bonn is a local and virtual international research center and a place of communication between science, politics and business. IZA is an independent nonprofit organization supported by Deutsche Post Foundation. The center is associated with the University of Bonn and offers a stimulating research environment through its international network, workshops and conferences, data service, project support, research visits and doctoral program. IZA engages in (i) original and internationally competitive research in all fields of labor economics, (ii) development of policy concepts, and (iii) dissemination of research results and concepts to the interested public.
\end{abstract}

IZA Discussion Papers often represent preliminary work and are circulated to encourage discussion. Citation of such a paper should account for its provisional character. A revised version may be available directly from the author. 


\section{ABSTRACT}

\section{On the Power of Childhood Impressions for Skill Formation: Initial Evidence and Unsettled Questions*}

Manifold childhood impressions result from the interactions with adult caregivers and the environment. These impressions, be they beneficial or detrimental, shape individual skill formation and achievement over the life cycle. The novelty of the paper is that it bonds two different, hitherto separated, research lines, one from economics, one from psychology, to discuss the relationship between childhood impressions and later achievement. First, selected recent findings on early life adversity and skill formation are presented. Second, a tool for improving self-regulation, called implementations intentions, is introduced, which may have the power to counteract negative childhood impressions later in live. The attempt to integrate the two approaches results in a discussion of unsettled questions and an outlook for future research.

JEL Classification: D87, I12, I21, J13

Keywords: early life adversity, implementation intentions, life cycle, skill formation

Corresponding author:

Friedhelm Pfeiffer

Centre for European Economic Research (ZEW)

P.O. Box 103443

68034 Mannheim

Germany

E-mail: pfeiffer@zew.de

\footnotetext{
* Support from the Leibniz Association (LA), Bonn, under the grant "Noncognitive Skills: Acquisition and Economic Consequences" is gratefully acknowledged. The views ex-pressed in this article are those of the author and do not necessarily reflect the views of the LA. Furthermore I would like to thank two anonymous referees for extremely helpful comments on an earlier version of the paper. All opinions and mistakes are my own.
} 
"And yet," said Wilhelm, "will not a genius be able to save himself, to heal the wounds that he has inflicted to himself?" "Not at all," said the stranger. "Or if so, then not very effectively. Nobody should ever believe that one's first youthful impressions can be counteracted." Johann Wolfgang von Goethe (1795) ${ }^{1}$

\section{Introduction}

A fundamental issue for optimal investment in human skill formation is whether the "first youthful impressions can be counteracted" (see the quote from Johann Wolfgang von Goethe), especially for children growing up in adverse family environments. Limited cognitive and self-regulatory competencies as well as developmental disorder, anxiety, school failure, or mortality may result from poor monitoring or maltreatment in childhood (Heckhausen and Heckhausen, 2008, Heckman, 2007, Holodynski et al. 2008, among others). For instance, the difference in life expectation between an adverse and a favourable family environment in childhood has been assessed to be eleven years (Frijters et al., 2010).

Is childhood a critical period in development in the sense that it is not possible to counteract adverse childhood impressions later in life or, if so, as the stranger in Goethe' novelty argues, "not very effectively"? Or is it possible to counteract negative childhood impressions with the help of powerful instructions improving self-regulation later in life?

The paper contributes to a burgeoning multidisciplinary literature on the role of early adversity and skill formation over the cycle. The novelty of the paper is that it tries to bond two different and hitherto separated research lines, one from economics the other from psychology. First, results from selected recent studies on pre- and perinatal organic and psychosocial risk factors as well as the socio-emotional home environment for children's achievement in adolescence are presented, based on the technology of skill formation (Blomeyer et al., 2009, forthcoming, Cunha et al., 2010). Supplementary, initial evidence on the relation between the time and region of birth and socio-economic outcomes in adulthood is provided. Second, implementation intentions, or if-then plans (Gollwitzer, 1993, 1999) that are designed to improve willpower and self-regulation strategies, are introduced. Implementation intentions may have the power to counteract negative childhood impressions that result in low self-regulatory capacities later in live. Finally, unsettled questions and new research lines are discussed.

\footnotetext{
${ }^{1}$ Eric A. Blackall and Victor Lange, trans., Wilhelm Meister's Apprenticeship (Princeton: Princeton University Press, 1995). The original version is: “Aber“, versetzte Wilhelm, „wird das Genie sich nicht selbst retten, die Wunden, die es sich geschlagen, selbst heilen?“ „Mitnichten“, versetze der andere, „Oder, wenigstens nur notdürftig; denn niemand glaube die ersten Eindrücke der Jugend überwinden zu können.” Wilhelm Meisters Lehrjahre (1795), $2^{\text {nd }}$ book, chap. 9, 129.
} 
Conclusions can be summarised as follows. The power of childhood impression and their consequences for later achievement still constitute a challenge for research. Individual development depends on beneficial interaction between children and adult caregivers. Whether childhood impressions become productive or unproductive will also be associated with social transaction and resources available later in life. If partners with powerful planning tools and economic resources become available, counteraction may become successful.

Although many features of interaction are universal, social reality varies to a significant degree in providing beneficial interaction. Despite the growing importance of schooling in advanced economies, socio-emotional home environment and paternal responsiveness still seem to constitute the most significant single resource available for children's skill formation. As a result of dynamic complementarity, part of benefits from investment into interaction in childhood emerges during the life cycle, and adult caregivers often fail to realise the whole benefit from their investment. As a consequence, investment during childhood often remains too low, especially for children growing up in adversity.

Counteracting negative childhood impressions in adulthood with the help of powerful instructions such as implementations intentions is necessary for improving self-regulation during adulthood. However, not all adults who suffer from negative childhood impressions have access to such tools. The optimal amount of interventions and the effectiveness of widespread and optimised applications during adulthood still need to be examined. This statement is true also for preventative strategies that intend to counteract early life adversity during childhood. More specifically the effectiveness of such interventions needs to be assessed and compared systematically in a life cycle framework.

The rest of the paper is organised as follows. Section 2 discusses findings from early life adversity and children's achievement. A supplement focuses on early life conditions and selected socio-economic outcomes in adulthood. Section 3 introduces implementation intentions and their role for improving self-regulation and individual progress. Section 4 explicates unsettled questions and concludes.

\section{Childhood impressions, achievement and individual progress}

From the cradle, the infant searches for a competent adult to regulate her emotions and needs (for a summary see Heckhausen and Heckhausen, 2008). Babies already exert an influence on the competent adult to form a relationship. In social reality, competent adults differ with regard to their competencies providing “contingent responses to the child's behaviour" (ditto, 394). Floor freedom and maternal responsiveness, which are among the 
most important factors for competence formation in early childhood, vary widely (for empirical evidence see Blomeyer et al., 2010, among others.

Over the life cycle, self-regulation and language, social, science and mathematical competences are developed during further interaction with adult caregivers, with friends and in schools. A low quality of responsiveness in parental-child interaction (e.g. mistreatment, violence or neglect) should contribute to lower self-regulation capacities.

From an economic point of view, responsiveness during the time of interaction is an investment made by the adult caregiver. The returns from these investments cannot be appropriated fully by the adult caregiver during the time of interaction with the child. On the one hand, the child may obtain a significant part of the returns in the form of better selfregulatory capacities, higher wages and a happier life, among others. On the other hand, society will also obtain part of the return, for instance through higher tax receipts over the life cycle or less maladaptive behaviour in adulthood. The investment behaviour of the adult caregiver will be governed by expected private costs and private benefits derived from investment. Since the social returns are disregarded, the amount of private investment in interaction with children will, as a rule, be too low, especially for disadvantaged children.

The following formulation, proposed by Heckman (2007), is helpful in highlighting the relationship between environment and investments (resulting in childhood impressions) and skill formation in a more formal way. It is used in the empirical part below (see section 3). Periods of development are indexed with $t$. One period may not be restricted to one year. Skill formation is formulated in equation (1):

$$
\Theta_{\mathrm{t}}=f_{\mathrm{t}}\left(H_{\mathrm{t}}, \Theta_{\mathrm{t}-1}, R, E_{t}\right)
$$

Skills at time $t, \Theta_{t}$, are modelled as a function of the stock of skills from the past period, $\Theta_{t-}$ ${ }_{1}$, the socio-emotional home environment, $H_{t}$, initial pre- and perinatal organic and psychosocial risk conditions, $R$, and by a vector of other influences not specified in the model under investigation, $E_{t}$. The technology that relates inputs to outputs, $f_{t}$, varies with the periods of development, as do inputs and outputs.

The vector of skills, summarised in $\Theta_{t}$, varies in the developmental process. Two examples may suffice to understand the notion of skills. Economics has defined the two broad categories of cognitive and non-cognitive skills (see Cunha and Heckman, 2007), covering a wide array of skills in each category, such as logical reasoning, memory, information processing speed, persistence, time preferences, self-regulation. Erikson (1959) categorised major 
stages of a child's psychosocial development from a psychological point of view. The first year in life is the developmental stage to experience trust versus mistrust; in early childhood (2-3 years) this turns to autonomy versus shame and doubt; in the preschool period (35 years) it is initiative versus guilt; at school age (6-11 years) it is industry versus inferiority; and at the advanced school age (12-20 years) it is identity versus role confusion. Life span development continues in the period of young adulthood (mid-20s), characterised by the experience of intimacy versus isolation; adulthood (to 60s), characterised by generativity versus stagnation and old age, characterised by ego integrity versus despair. Some of Erikson's constructs are directly related to the economic term skills (for instance industry), others more indirectly (for instance trust).

The dimension of the vector of skills in each category increases and evolves during development and interaction, which is one reason why research on the causes and consequences on skill formation is performed in a number of disciplines such as economics, pedagogics, psychology and sociology. Over the life span, the vector becomes a more and more complex construct that may be called human capital, character, or personality. It comprises basic cognitive and non-cognitive abilities, vocational, academic, emotional and social skills, and manifold further experiences derived from the interaction with friends and the environment in the process of development.

The suggestion put forward by Goethe, namely that childhood (or youthful) impressions are related to performance later in life put some restrictions on the function $f_{t}$ (see Heckman, 2007). First, a skill is said to exhibit self-productivity if its own first derivative is positive, equation (2):

$$
\frac{\partial \Theta_{t}}{\partial \Theta_{t-1}}\left(\Theta_{t-1}, H_{t}, R, E_{t}\right) \succ 0 \text { (self-productivity) }
$$

Self-productivity means that skills acquired at one stage in the development process foster the formation of new skills at later stages, without relying on further investment or impressions. In the case of positive cross derivatives, there are synergies in the formation of skills, called cross-productivity, equation (3):

$$
\frac{\partial^{2} f_{t}\left(\Theta_{t-1}, H_{t}, R, E_{t}\right)}{\partial \Theta_{t-1} \partial \Theta_{t-1}^{\prime}} \geq 0 \text { (cross-productivity) }
$$

For example, higher cognitive skills may foster self-regulation as part of non-cognitive skills and vice versa. 
Dynamic complementarities arise if the returns on later investments-be it formal education in schools to improve language and science competencies or life-long learning activities during a working life-depend on the stock of skills acquired in the past, equation (4):

$$
\frac{\partial^{2} f_{t}\left(\Theta_{t-1}, H_{t}, R, E_{t}\right)}{\partial \Theta_{t-1} \partial H_{t}} \geq 0 \text { (dynamic complementarity) }
$$

The property of dynamic complementarity summarizes why the healthier, brighter and more motivated children should on average achieve more success in schools and on the labour market and may experience a happier and better life. Children with superior language abilities, memory and a more sophisticated self-regulation strategy, should on average be better integrated into social life.

Empirical research is concerned with the measurement of the various impressions that may exert an influence on development and skills at various stages across the life span. It is not intended (and not even possible) to survey the research that has been carried out in economics, pedagogics, psychology, sociology, among others, to uncover the association between internal and external factors and skill formation during the life cycle. In what follows two recent studies on initial risk conditions, investments and children's achievement will be discussed that explicitly refers to the technology of skill formation (see the above equations) and utilises longitudinal cohort data in their empirical part.

\section{Evidence on early life adversity and skill formation}

The Mannheim longitudinal study of children at risk (Bloymeyer et al., 2009, Laucht et al., 1997, 2004) aims at following infants at risk for later developmental disorders in order to examine the impact of initial adverse conditions on the probability of negative health and socio-economic outcomes, starting in the year 1986. It includes first-born infants, growing up with German-speaking parents in a West German urban conglomeration (the RhineNeckar region) of medium size.

In the Mannheim study infants were rated according to the degree of "organic” risk and the degree of "psychosocial” risk. Each risk factor was scaled as non-risk, moderate risk or high risk. Organic risk factors include conditions such as preterm birth or neonatal complications, while psychosocial risk factors are defined as being born into adverse home environments, such as parents of low education, early parenthood, or parents with a mental disorder. According to this rating, children were assigned to one of the nine groups resulting from the two-factor $3 \times 3$ design. 
All groups are approximately of equal size, with a slight oversampling in the high-risk combinations and with sex distributed evenly in all subgroups. This study is especially valuable for research on the power of youthful impressions because the nine cells of the initial risk matrix constitute a set of nine types of impressions, differing in the degree of both organic and the psycho-social factors. Psychometric assessments of cognitive abilities, standardised intelligence quotient (IQ), were conducted at infancy (3 months), toddlerhood (2 years), preschool age (4.5 years), elementary school age (8 years) and secondary school age (11 years). A non-cognitive skills assessment is available, defined as persistence $(P)$, which is associated with the ability to goal shielding in the presence of distractors and obstacles. Assessments are based on behaviour observations, parent interviews and expert ratings, also beginning at the age of 3 months.

Table 1 summarises the means of the $I Q$ and $P$ in the nine risk groups at the ages of 3 months and 11 years.

Table 1: Children's abilities at 3 months and 11 years evaluated in the risk matrix (means; SD in brackets)

\begin{tabular}{|c|c|c|c|c|c|c|c|}
\hline & & \multicolumn{6}{|c|}{ Psychosocial Risk } \\
\hline & & \multicolumn{2}{|c|}{ no-risk } & \multicolumn{2}{|c|}{ Moderate } & \multicolumn{2}{|c|}{ high } \\
\hline & & \multicolumn{6}{|c|}{ IQ (Intelligence Quotient) } \\
\hline & & 3 months & 11 years & 3 months & 11 years & 3 months & 11 years \\
\hline \multirow{5}{*}{ 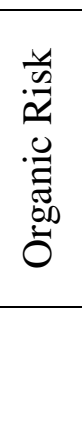 } & no-risk & $\begin{array}{r}103^{*} \\
(13.5)\end{array}$ & $\begin{array}{r}108 * \\
(15.3)\end{array}$ & $\begin{array}{c}102^{*} \\
(16.7)\end{array}$ & $\begin{array}{r}107^{*} \\
(16.3)\end{array}$ & $\begin{array}{r}96 * \\
(15.9)\end{array}$ & $\begin{array}{r}100^{*} \\
(18.9)\end{array}$ \\
\hline & moderate & $\begin{array}{r}101^{*} \\
(16.0)\end{array}$ & $\begin{array}{r}105^{*} \\
(10.4)\end{array}$ & $\begin{array}{r}99 * \\
(16.5)\end{array}$ & $\begin{array}{r}98 * \\
(13.3)\end{array}$ & $\begin{array}{r}97^{*} \\
(16.3)\end{array}$ & $\begin{array}{r}97 \\
(19.2)\end{array}$ \\
\hline & High & $\begin{array}{r}95 \\
(13.2) \\
\end{array}$ & $\begin{array}{r}101^{*} \\
(20.0)\end{array}$ & $\begin{array}{r}93 \\
(17.4) \\
\end{array}$ & $\begin{array}{r}92 \\
(24.0) \\
\end{array}$ & $\begin{array}{r}88 \\
(19.8) \\
\end{array}$ & $\begin{array}{r}87 \\
(27.3) \\
\end{array}$ \\
\hline & & \multicolumn{6}{|c|}{ P (Persistence score) } \\
\hline & & 4.5 years & 11 years & 4.5 years & 11 years & 4.5 years & 11 years \\
\hline \multirow{3}{*}{ 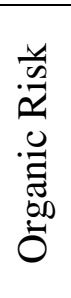 } & no-risk & $\begin{array}{c}3.82^{*} \\
(0.68)\end{array}$ & $\begin{array}{r}4.27^{*} \\
(0.54)\end{array}$ & $\begin{array}{r}3.50^{*} \\
(0.73)\end{array}$ & $\begin{array}{c}4.13^{*} \\
(0.59)\end{array}$ & $\begin{array}{r}3.17 \\
(0.83)\end{array}$ & $\begin{array}{r}3.84 \\
(0.79)\end{array}$ \\
\hline & moderate & $\begin{array}{c}3.54 * \\
(0.63)\end{array}$ & $\begin{array}{l}4.02 * \\
(0.53)\end{array}$ & $\begin{array}{r}3.38 \\
(0.75)\end{array}$ & $\begin{array}{r}3.87 \\
(0.59)\end{array}$ & $\begin{array}{r}3.20 \\
(0.80)\end{array}$ & $\begin{array}{r}3.63 \\
(0.73)\end{array}$ \\
\hline & high & $\begin{array}{l}3.61^{*} \\
(0.64)\end{array}$ & $\begin{array}{l}3.99 * \\
(0.56)\end{array}$ & $\begin{array}{r}3.14 \\
(0.70)\end{array}$ & $\begin{array}{r}3.71 \\
(0.64)\end{array}$ & $\begin{array}{r}3.07 \\
(0.77)\end{array}$ & $\begin{array}{r}3.55 \\
(0.91)\end{array}$ \\
\hline
\end{tabular}

Taken from Blomeyer et al. (2009), 364 observations; IQ is normalised to mean 100 and SD 15 in the normative group; persistence varies between $1.0,1.1, \ldots$ (low) and 5.0 (high); * indicates the significance of differences relative to the highest-risk group at the 5 per cent level. 
The importance of initial impressions, risk conditions, for children's basic skills are demonstrated, in line with other studies on child development (Beckett et al., 2006; Cunha et al., 2006; O’Conell and Sheikh, 2008, among others). Unfavourable consequences of initial organic and psychosocial risks persist until adolescence and have cumulative effects on basic abilities. There is a monotonic significant decrease in the IQ in both risk dimensions with increasing differences between the ages of 3 months and 11 years. Organic and psychosocial risk factors exhibit equally negative effects on basic skills but are specific to the areas they affect. While the impact of early organic risks concentrates on cognitive functioning, psychosocial risks primarily influence cognitive and socio-emotional functioning (that is $P$ ). For instance, there is a 23 per cent difference between the no-risk and the highest-risk group of children under persistence at the age of 4.5 years (3.8 vs. 3.1, see Table 1). The matrix shows a particularly dramatic decrease in persistence in the psychosocial dimension.

To assess dynamic complementarities, the initial risk matrix and its impact on children's academic and social achievement at school age is examined. The outcomes under investigation include hobbies (interests) and the peer relationship (peers), as well as the grade in Reading (grades vary from 1, excellent, to 6, insufficient) at elementary school age (8 years), and the higher-track secondary school attendance, Gymnasium, at the age of 15. In Germany, school choice takes place, as a rule, after the age of 10, and academic achievement in elementary school is relevant for tracking. Table 2 contains the means of the variables at elementary school for all cells of the risk matrix and the percentage of children attending the Gymnasium at secondary school age (15 years).

Results demonstrate that childhood impressions, measured as initial risk conditions, matter for school and social competencies at the age of 8 years, indicating the presence of dynamic complementarities. Risk effects cumulate, at least to some degree. On average, initial psychosocial risk seems to be more harmful than initial organic risks. The gaps in average school competencies, grade in reading, social outcomes such as interests and peer relations at the age of 8 years are significant. 45 per cent of the children under observation attend a Gymnasium. Again, the initial risk matrix matters. In the highest risk group, only 15 per cent of the children attend the Gymnasium, compared to 74 per cent in the no-risk group.

The evidence on dynamic complementarities in skill formation is suggestive. Initial organic and psychosocial risk factors that condense a rich variety of childhood impression in nine 
treatments matter for later development in a specifiable way. In what follows the role of subsequent investments for the development of skills is examined.

Table 2: Academic and social achievement at age 8 and higher-track secondary school attendance at age 11

\begin{tabular}{|c|c|c|c|c|}
\hline & & \multicolumn{3}{|c|}{ Psychosocial Risk } \\
\hline & & no-risk & moderate & High \\
\hline \multicolumn{5}{|c|}{ Grades in reading ${ }^{a)} /$ interests / peers at age 8} \\
\hline \multirow{3}{*}{ 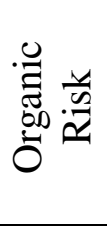 } & no-risk & $2.0^{*} / 5.1 * / 4.8^{*}$ & $2.2 * / 4.9 * / 4.6 *$ & $2.3 / 4.4 / 4.6^{*}$ \\
\hline & moderate & $2.2 * / 5.0 * / 4.5 *$ & $2.4 / 4.4^{*} / 4.5^{*}$ & $2.8 / 4.1 / 4.4$ \\
\hline & high & $2.1 * / 4.9 * / 4.8 *$ & $2.4 / 4.3 / 4.4$ & $2.8 / 3.9 / 4.0$ \\
\hline \multicolumn{5}{|c|}{$\begin{array}{l}\text { Higher-track secondary school attendance "Gymnasium" / } \\
\text { "Realschule" / "Andere” }{ }^{\text {b) }} \text { at age } 11 \text { (in per cent) }\end{array}$} \\
\hline \multirow{3}{*}{ 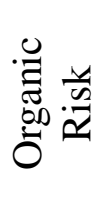 } & no-risk & $74 * / 24 * / 02 *$ & $77 * / 09 * / 14^{*}$ & $43 / 21 * / 36$ \\
\hline & moderate & $45 / 40^{*} / 15^{*}$ & 38 / 38* / 34* & 33 / 23 / 44 \\
\hline & high & $54 * / 23 * / 23 *$ & $27 / 38$ / 45 & 15 / 28 / 67 \\
\hline
\end{tabular}

$\overline{\text { Blomeyer et al. (2009), }{ }^{a)} \text { in the German educational system grades range from } 1.0 \text { (excellent) to } 6.0}$ (insufficient), b) "Haupt-“, "Förder-“ and "Waldorfschule”, *indicates significant mean differences relative to the high-risk group at the 5 per cent level.

\section{Evidence on the technology of skill formation}

Findings from two recent studies on central parameters of the technology of skill formation are discussed. Blomeyer et al. (2009) is based on the Mannheim Study of Children at Risk, whereas Cunha et al. (2010) is based on the children's sample from the National Longitudinal Study of Youth. Both studies examine the relationship between basic skills in $t$ with parental monitoring $(H$, a measure of the socio-emotional family environment and an indicator of family investment, which should have a strong relationship to childhood impressions) in period $t$ and the stock of basic skills available from period $t$-1. Cunha et al. (2010) differentiate between two developmental stages, 0 to 5-6 years, and 5-6 to 13-14 years and estimate a model that incorporates preferences and investment decisions of parents. In Blomeyer et al. (2009) estimates are performed for five major stages of development.

In Blomeyer et al. (2009) it is assumed that equation (1) (introduced above) can be represented in a Cobb-Douglas form. Taking the natural logarithm from the Cobb-Douglas representation of equation (1) and using lower case character yields equation (5): 


$$
\theta_{\mathrm{t}, \mathrm{i}}^{\mathrm{j}}=\alpha_{0, \mathrm{t}}^{\mathrm{j}} \cdot \mathrm{r}+\alpha_{\mathrm{t}}^{\mathrm{h}, \mathrm{j}} \cdot h_{\mathrm{t}, \mathrm{i}}+\alpha_{\mathrm{t}}^{\mathrm{j}} \cdot \theta_{\mathrm{t}-1, \mathrm{i}}^{\mathrm{j}}+\alpha_{\mathrm{t}}^{\mathrm{k}, \mathrm{j}} \cdot \theta_{\mathrm{t}-1, \mathrm{i}}^{\mathrm{k}}+\alpha_{\mathrm{t}}^{\mathrm{l}, \mathrm{j}} \cdot \theta_{\mathrm{t}-1, \mathrm{i}}^{\mathrm{l}}+\varepsilon_{\mathrm{t}, \mathrm{i}}^{\mathrm{j}}
$$

where $j, k, l$ are indices for the three basic abilities IQ, MQ and $P$; $i=1$ and $N$ is an index for the children. $r$ contains all nine cells of the initial two-dimensional risk matrix. $h$ characterises the socio-emotional home environment. All parameters can be interpreted as partial elasticity. According to Equation (5) competencies can be produced continuously by the home environment and the stock of competencies available from the past period. The relative contributions of $h_{t}$ and $\theta_{t-1}$ in $t$ will depend on the values of $\alpha_{t}$, the partial elasticity of the Cobb-Douglas function. While belonging to a risk group may have lasting effects on the level of competencies, the functional form allows that the competencies remain malleable in each period.

The Cobb-Douglas representation of competence formation has advantages and disadvantages (see Blomeyer et al., 2013). The main (and decisive) advantage arises from its flexibility and the low number of parameters to assess the role of home resources, selfproductivity, and synergies in competence formation using a small data set. The main disadvantage is the assumption that the elasticity of substitution between past competencies and current home environment is one. In Cunha et al. (2010), the estimated elasticity is sometimes lower, sometimes higher than one.

The comparison of findings reveals similarities and dissimilarities (see Table 3). Both studies show that the importance of investment and self-productivity for skill formation changes in a manner specific to the developmental stage and the skill investigated. Both studies suggest a robust role of family investments (resulting in various childhood impressions) for development. For cognitive skills, investment seems to be more relevant in early childhood. Its importance decreases after preschool age. For non-cognitive skills, investment seems to be equally relevant at all developmental stages. The magnitude of the point estimates suggests a (moderately) stronger association between investments and skills in Blomeyer et al. (2009) compared to Cunha et al. (2010).

Both studies demonstrate that self-productivity increases for cognitive skills. It is relatively low in infancy and toddlerhood and relatively higher at preschool age and again at school age. They also demonstrate that self-productivity increases for non-cognitive skills. Selfproductivity is higher in Cunha et al. (2010) starting in infancy and throughout school age. The studies further indicate that cross-productivity is relevant for development. While 
Blomeyer et al. (2009) demonstrate the relevance of cross-productivity for all developmental stages, in Cunha et al. (2010) cross-productivity mainly enhances skills until the ages of 5-6 years. The dissimilarities may result from differences in the skills considered in both studies (Blomeyer et al., 2009, also take motor skills into account - in addition to basic cognitive and non-cognitive skills - which is not the case in Cunha et al., 2010) or in the different estimation methods.

Table 3: Self-productivity, cross-productivity and investment (partial elasticity)

\begin{tabular}{|c|c|c|c|c|c|}
\hline \multicolumn{6}{|c|}{ Cognitive skills } \\
\hline \multicolumn{6}{|c|}{ Cunha et al. (2010) } \\
\hline & \multicolumn{2}{|c|}{$0-5 / 6$ years } & \multicolumn{3}{|c|}{ 5/6-13/14 years } \\
\hline Self-productivity & \multicolumn{2}{|c|}{$0.49 *$} & \multicolumn{3}{|c|}{$0.90 *$} \\
\hline Cross-productivity & \multicolumn{2}{|c|}{$0.08^{*}$} & \multicolumn{3}{|c|}{0.01} \\
\hline Current Period Investment & \multicolumn{2}{|c|}{$0.23 *$} & \multicolumn{3}{|c|}{$0.02 *$} \\
\hline \multicolumn{6}{|c|}{ Blomeyer et al. (2009) } \\
\hline & 3 months & 2 years & 4.5 years & 8 years & 11 years \\
\hline Self-productivity & n.a. & $0.23 *$ & $0.53 *$ & $0.84 *$ & $0.89 *$ \\
\hline Cross-productivity & n.a. & $0.20 *$ & $0.11 *$ & $0.33^{*}$ & $0.23 *$ \\
\hline Home Environment & $0.55 *$ & $0.38 *$ & $0.38 *$ & 0.19 & 0.17 \\
\hline \multicolumn{6}{|c|}{ Noncognitive skills } \\
\hline \multicolumn{6}{|c|}{ Cunha et al. (2010) } \\
\hline & \multicolumn{2}{|c|}{$0-5 / 6$ years } & \multicolumn{3}{|c|}{ 5/6-13/14 years } \\
\hline Self-productivity & \multicolumn{2}{|c|}{$0.65 *$} & \multicolumn{3}{|c|}{$0.87^{*}$} \\
\hline Cross-productivity & \multicolumn{2}{|c|}{0.00} & \multicolumn{3}{|c|}{0.008} \\
\hline Current Period Investment & \multicolumn{2}{|c|}{$0.15^{*}$} & \multicolumn{3}{|c|}{$0.05^{*}$} \\
\hline \multicolumn{6}{|c|}{ Blomeyer et al. (2009) } \\
\hline & 3 months & 2 years & 4.5 years & 8 years & 11 years \\
\hline Self-productivity & n.a. & -0.08 & $0.18^{*}$ & $0.29 *$ & $0.31 *$ \\
\hline Cross-productivity & n.a. & $0.25 *$ & $0.57 *$ & $0.47 *$ & $0.34 *$ \\
\hline Home Environment & $0.29 *$ & $0.37 *$ & $0.50 *$ & $0.43 *$ & 0.28 \\
\hline
\end{tabular}

* indicates statistical significance at the 5 per cent level.

To sum up, children from adverse home environments appear to suffer doubly due to negative impressions during childhood and insufficient support during school age. The significant amount of stability in the economic and socio-emotional home resources over time, 
demonstrated for the Mannheim children (see Blomeyer et al., forthcoming), therefore seems to be one major reason for the increase of inequality in development (as shown in Table 1 above). Children suffering from negative impressions during early childhood will also suffer from continuing negative impressions during mid and late childhood with a significant probability.

\section{Supplementary evidence on the role of early conditions for later outcomes}

In this section, a set of socio-economic outcomes in adulthood is investigated, assessed by means of samples for two cohorts of workers, aged 30 and 40 years, growing up in different socio-economic different environments. The samples consist of East and West German workers and have been extracted from the German Socio-Economic Panel (see Wagner et al. 2007). The samples from the two regions are designed in such a way that the initial conditions prevailing during childhood differed significantly. Four cohorts are available from West Germany (born 57/61; 62/66; 67/71; 72/76), three for East Germany (born 62/66; 67/71; 72/76) observed at the age 30 years, two for those aged 40 years from West Germany (born 57/61; 62/66) and one for East Germany (62/66). Thus all workers in the sample grew up before unification took place. Furthermore, separate samples were taken for males and females.

In what follows, the socio-economic outcomes associated with the different initial conditions are demonstrated. Four outcomes are examined: education (in years), wages (in 2006 $€)$, tenure (in years) and reported life satisfaction (score on an 11-point rating scale). Table A1 documents the findings for males, Table A2 for females. Test statistics indicate significant group differences at the 5 per cent level.

Average wages for East German workers are lower than those for West German workers. The result holds for all birth cohorts, at all ages, and for both males and females. The average wage differences are higher for males (around 25 per cent) compared to females (around 20 per cent). One reason is that the cohorts of females from East Germany born before 1972 acquired more years of education on average compared to West German females from the same cohort. In the cohort of workers born between 1972 and 1976, the difference in years of education is, however, no longer significant. On average, wages of cohorts born after the baby boom are not higher than those of the baby boomer cohorts (57/61). At the age of 30 years, average wages of West German male workers born between 1957 and 1961 are higher compared to the later cohorts. The difference is no longer significant at the age of 40 years. The average tenure for East German male workers is lower than 
that for West German workers, although the difference is not significant in all cohorts. Average life satisfaction among East Germans is lower than that among West Germans. The result holds for all birth cohorts, at all ages and for both males and females.

To further assess the relationship between individual characteristics at birth and socioeconomic outcomes in adulthood, longitudinal data with information starting in infancy are needed, such as the MARS data. More representative data are still rare, although progress is under way. Referring to three recent studies may suffice. As already mentioned in the introduction, the difference in life expectation between an adverse and a favourable family environment in childhood was assessed to be eleven years based on the Byod-Orr data, which cover a time period of more than hundred years in Great Britain (Frijters et al., 2010). According to van den Berg et al. (2006, 300), "being born in a recession is associated with an 8-percent increase in the mortality rate after the first year of life”. Findings are based on approximately 14,000 individuals born in the Netherlands in the period 18121912, who were followed up to the year 2000. According to Black et al. (2007), a 10-per cent increase in birth weight increases school success and wages by roughly 1 per cent.

The supplementary evidence confirms that socio-emotional and economic conditions early in life (implying differences in childhood impressions) seem on average to be associated with relevant outcomes in adulthood, such as wages and life satisfaction.

\section{Strategies to counteract the consequences of negative impressions}

Individuals strive for goals (desired outcomes) and optimise in the face of restrictions. For instance, optimal educational investments require solving an intertemporal maximising problem under restrictions. In the economic textbook model, a utility function values desired outcomes over the life cycle, and individuals choose their effort in order to maximise life time utility. However, a lack of willpower (“i.e. the potential to exert self-control”; Gollwitzer et al., 2008, called also akrasia, “weakness of will” by Aristotle, see Ainslie, 2001), manifested in impatience, procrastination, alcohol or drug addiction, and violent activities, among others, may restrict the capacity of individuals to solve such maximisation problems. Since a significant part of these self-regulatory abilities is formed during childhood (see Baumeister and Tierney, 2011, Benabou and Tirole, 2004, and Section 2 above), childhood impressions are beneficial or detrimental for later achievement.

Is it possible to counteract negative childhood impressions that may be associated with akrasia? One approach elaborated in psychology shall be discussed. According to 
Gollwitzer et al. (2008), people have to solve two different sets of problems in pursuing their goals. First, they have to set themselves goals to be able to maximise utility. Second, they have to regulate their efforts in such a manner as to implement these goals (Gollwitzer, 1993, 1999). Obstacles from external events (an often cited example are the Sirens in the Odyssey) as well as inner states (such as being tired, "bad" habits from childhood impressions, e.g. due to negative self-efficacy when children are told at home that there is no use in trying hard because they are not going to move up the social ladder anyway) may deter adults from achieving success.

Gollwitzer et al. (2008) identify the following steps to be solved in the second task: "getting started with goal pursuit”, "staying on track”, “calling a halt”. Furthermore, people should be able to not overstrain themselves in one goal over the life cycle in order to remain openminded for new goals. In a number of experimental studies, Gollwitzer's research team demonstrated the superiority of "implementation intentions". Based on 94 independent studies with over 8,000 participants, a self-regulation strategy of forming if-then plans, “implementation intentions”, facilitated achievement in addition to "goal intentions” alone.

One example from academic test performance may suffice to understand the idea behind these superior if-then plans. Bayer and Gollwitzer (2007) asked female high school students to complete a math test under two different instructions. The desired outcome was to solve as many tasks as possible in the math test. Half of the students received the instruction: "I will correctly solve as many tasks as possible”, as their goal intention. For the second half of the students, a "self-efficacy strengthening implementation intention" was added: “And if I start a new task, then I will tell myself: I can solve this task!” In the if-part, a goal-relevant situation was specified (“if I start a new task”) together with a proper goaldirected response in the then-part (“then I will tell myself: I can solve this task”).

In the study, the goal-directed response was a motivational response, a mere "preprogrammed, inner self-motivating speech" that sufficed to produce better test performance. Such implementation intentions in the form of if-then plans seem to produce the difference. It was not sufficient when students were instructed with an additional goal intention: “And I will tell myself: I can solve these problems!” However, if-then plans helped to improve willpower in academic performance because they trigger "automatic" instead of “effortful, conscious” processes (Gollwitzer, 1999). Superiority of these simple if-thenplans stems from improving brain performance. With such an instruction in mind, more brain capacity is left for solving the academic task. 
In the experimental settings the experimenter takes on the task of optimising the selfregulation strategy of individuals, and this seems to work fine. Implementation intentions are fairly general and not restricted to foster academic performance. There is a wealth of findings from other examples including improved achievement in sport competition, in negotiations or with children suffering under action control (see the summary in Gollwitzer et al., 2008).

\section{Unsettled questions and research outlook}

Childhood impressions exert long lasting influences in the fast developing brain. Poor responsiveness generates different impressions compared to care and affection. Some of these impressions remain unconscious, and some may become harmful, others not, depending on various challenges. Whether childhood impressions become productive or unproductive will also be associated with social transaction and resources available later in life. If partners with powerful planning tools and economic resources become available, counteraction may become effective.

Finding a partner to monitor action and counteracting childhood impressions is not easy and may sometimes be even impossible in social reality. Experimental evidence suggests that counteracting negative childhood impressions later in life with simple, although seemingly powerful, instructions is possible. A policy that tries to foster achievement in adulthood with implementation intentions can be termed a remedial policy. Evidence on a widespread application of such remedial interventions is currently not available. Future research is needed to design such policies and assess their effectiveness in social reality. Is it only the "geniuses" among us that improve achievement or also common persons suffering from low willpower as a result of negative childhood impression? Are simple if-then plans effective also for solving sets of complex tasks, for example finding a job or finishing school successfully, or do they only perform well for less complex tasks?

Similar research questions emerge also for preventative strategies that are designed to help disadvantaged children during childhood. According to Cunha et al. (2006), early childhood interventions have been effective to improve social achievement and life cycle human capital skill formation (see also Pfeiffer and Reuß, 2008). However, there is still not much known about the relative effectiveness of optimised preventative intervention in early childhood compared to remedial intervention in adulthood. On the one hand, a preventative strategy will be relatively costly since the support ratio (adult caregiver per infant) needs to 
be relatively high during childhood (around 1 to 3). Furthermore, detecting neglect and poor monitoring that result in negative impressions is costly. Some uncertainty on the predictive power of rating schemes will remain. On the other hand, the cost of remedial interventions in the form of simple if-then plans should be low per year. However, such interventions often have to be conducted over long periods, maybe even over the entire life cycle, to remain effective. Since studies that compare preventative and remedial interventions for the same group of individuals are missing, future research should try to fill this gap.

Such research will have to solve a number of crucial tasks. Collecting data on competencies from infancy onwards and identifying the main formation factors and interventions needs to be improved, as well as detecting neglect and poor monitoring. Even if available, measurement may remain ambivalent, and normative issues, such as the fundamental role of families and the government for skill formation, have to be dealt with. Hopefully, research will continue by means of multidisciplinary studies and will thoroughly collect and analyse longitudinal data with better theories and enhanced information on childhood impressions, counteraction measures and outcomes.

\section{References}

Ainslie, George (2001). Breakdown of Will. Cambridge: Cambridge University Press.

Baumeister, Roy F. and Tierney, J. (2011). Willpower: Rediscovering the greatest human strength. New York: Penguin Press.

Bayer, Ute C. and Peter Gollwitzer (2007). "Boosting Scholastic Test Scores by Willpower: The Role of Implementation Intentions”. Self and Identity 6: 1-19.

Benabou, Roland J.M. and Jean Tirole (2004). "Willpower and Personal Rules”. Journal of Political Economy 112 (4): 848-87.

Black, Sandra E., Paul J. Devereux and Kjell Salvanes (2007). "From the Cradle to the Labor Market? The Effect of Birth Weight on Adult Outcomes”. The Quarterly Journal of Economics 122 (1): 409-39.

Blomeyer, Dorothea, Katja Coneus, Manfred Laucht and Friedhelm Pfeiffer (2009). ”Initial Risk Matrix, Home Resources, Ability Development and Children's Achievement.” Journal of the European Economic Association 7(2-3), 638-648.

Blomeyer, Dorothea, Manfred Laucht, Friedhelm Pfeiffer and Karsten Reuß (2010). "Mutter-Kind-Interaktion im Säuglingsalter, Familienumgebung und Entwicklung früher kognitiver und nichtkognitiver Fähigkeiten: Eine prospektive Studie.“ DIWVierteljahreshefte zur Wirtschaftsforschung 79 (3), 11-26.

Blomeyer, Dorothea, Katja Coneus, Manfred Laucht and Friedhelm Pfeiffer (Forthcoming). "Early life adversity and children's competence development: evidence from the Mannheim Study of Children at Risk.” Journal of Economics and Statistics. 
Cunha, Flavio, James J. Heckman, Lance Lochner and Dimitri Masterov (2006). "Interpreting the Evidence on Life Cycle Skill Formation”. In: Erik Hanushek and Finis Welch (eds.), Handbook of the Economics of Education. Amsterdam: North-Holland.

Cunha, Flavio and James J. Heckman (2007). “The Technology of Skill Formation”. The American Economic Review 97 (2): 31-47.

Cunha, F., Heckman, J. J. and Schennach, S. M. (2010). "Estimating the Technology of Cognitive and Noncognitive Skill Formation”. Econometrica 78(3) 883-931.

Erikson, Erik (1959). “Identity and the Life Cycle”. Psychological Issues 1(1).

Frijters, Paul, Timothy Hatton, Richard M. Martin, and Michael A. Shields (2010). "Childhood Economic Conditions and Length of Life: Evidence from the UK Boyd Orr Cohort, 1937-2005”. Journal of Health Economics, 29(1), 39-47.

Gollwitzer, Peter (1993). “Goal Achievement: The Role of Intentions”. European Review of Social Psychology 4: 141-85.

Gollwitzer, Peter (1999). “Implementation Intentions: Strong Effects of Simple Plans”. American Psychologist 54(7): 493-503.

Gollwitzer, Peter, Caterina Gawrilow and Gabriele Oettingen (2008). "The Power of Planning: Effective Self-Regulation of Goal Striving”. New York University: Manuscript.

Heckhausen, Jutta and Heinz Heckhausen (2008). “Motivation and Development”. In: Jutta Heckhausen and Heinz Heckhausen (eds.), Motivation and Action. Cambridge: Cambridge University Press. Chap. 15.

Heckman, James J. (2007). "The Economics, Technology and Neuroscience of Human Capability Formation”. Proceedings of the National Academy of Sciences 104 (3): 132250-5.

Holodynski, Manfred., Freia Stallmann, Dorothee Seeger (2008), Entwicklung als soziokultureller Lern-prozess: Die Bildungsbedeutung von Bezugspersonen für Kinder. P. 91129 in: Frühkindliche Bildung und Betreuung, in Thomas Apolte, Antje Funcke (Eds.), Nomos Ver-lagsgesellschaft, Baden-Baden.

Laucht, Manfred, Günter Esser and Martin H. Schmidt (1997). "Developmental Outcome of Infants Born with Biological and Psychosocial Risks”. Journal of Child Psychology and Psychiatry 38 (7): 843-54.

Laucht, Manfred, Martin H. Schmidt and Günter Esser (2004). “The Development of Atrisk Children in Early Life”. Educational and Child Psychology 21 (1): 20-31.

O’Connell, M., Sheikh, H. (2008). “Achievement-related Attitudes and the Fate of "Atrisk” Groups in Society”. Journal of Economic Psychology 29(4): 508-21.

Pfeiffer, Friedhelm and Karsten Reuß (2008). “Age-dependent Skill Formation and Returns to Education”. Labour Economics 15 (4): 631-46.

Van den Berg, Gerard, Maarten Lindeboom and France Portrait (2006). "Economic Conditions Early in Life and Individual Mortality”. The American Economic Review 96 (1): 290-302.

Wagner, G. G., J. R. Frick and J. Schupp (2007), The German Socio-Economic Panel Study (SOEP) - Scope, Evaluation and Enhancements, Schmollers Jahrbuch - Journal of Applied Social Science Studies 127 (1), 139 - 169. 
Table A1: Socio-economic outcomes of cohorts East and West German female workers, evaluated at the ages of 30 and 40 (means; in brackets SD)

\begin{tabular}{|c|c|c|c|c|}
\hline Cohorts (\# of obs.) & $\begin{array}{c}\text { Education } \\
\text { in years }\end{array}$ & $\begin{array}{c}\text { Wage }^{12} \\
\text { in } €\end{array}$ & $\begin{array}{l}\text { Tenure }^{1} \\
\text { in years }\end{array}$ & $\begin{array}{c}\text { Life satis- } \\
\text { faction }^{3} \\
\text { 11s scale }\end{array}$ \\
\hline \multicolumn{5}{|c|}{ at age 30} \\
\hline West Germany ${ }^{4}$ & \multirow{5}{*}{$\begin{array}{l}12.0(2.4) \\
12.0(2.4) \\
12.3(2.4) \\
12.8(2.7)^{\mathrm{a}}\end{array}$} & & & \\
\hline 1957-61 (95 - 366) & & $14.8(3.6)$ & $6.6(4.6)$ & $7.4(1.6)$ \\
\hline 1962-66 (135 - 415) & & $14.4(3.6)$ & $5.7(4.2)$ & $7.1(1.8)$ \\
\hline 1967-71 (143 - 339) & & 13.7 (3.3) & $5.3(4.3)$ & $7.2(1.6)$ \\
\hline $1972-76(87-211)$ & & $14.6(4.4)$ & $5.0(4.0)$ & $7.1(1.8)$ \\
\hline \multicolumn{5}{|l|}{ East Germany ${ }^{5}$} \\
\hline 1962-66 (85 - 210) & \multirow{3}{*}{$\begin{array}{l}12.7(2.1)^{b} \\
12.7(2.2)^{b} \\
13.1(2.2)\end{array}$} & $10.8(3.1)^{b}$ & $4.7(4.2)$ & $6.2(1.9)^{\mathrm{b}}$ \\
\hline 1967-71 (61 - 174) & & $11.0(3.5)^{\mathrm{b}}$ & $5.6(3.9)$ & $6.8(1.6)^{\mathrm{ab}}$ \\
\hline $1972-76(53-150)$ & & $11.2(3.9)^{\mathrm{b}}$ & 4.8 (3.9) & $6.9(1.4)^{\mathrm{a}}$ \\
\hline \multicolumn{5}{|c|}{ at age 40} \\
\hline \multicolumn{5}{|l|}{ West Germany } \\
\hline $1957-61 \quad(71-316)$ & $12.0(2.5)$ & $15.5(5.4)$ & $9.6(7.6)$ & $7.1(1.7)$ \\
\hline $1962-66(78-325)$ & $12.3(2.5)$ & $16.2(5.3)$ & $10.6(7.5)$ & $6.9(1.7)$ \\
\hline \multicolumn{5}{|l|}{ East Germany } \\
\hline 1962-66 (68 - 156) & $12.7(2.1)^{\mathrm{c}}$ & $12.7(4.7)^{\mathrm{c}}$ & $9.4(6.4)$ & $6.1(1.8)^{\mathrm{c}}$ \\
\hline $\begin{array}{r}\text { Total Sample (867- } \\
2,608)\end{array}$ & $12.3(2.4)$ & $13.7(4.3)$ & $6.5(5.4)$ & $7.0(1.7)$ \\
\hline
\end{tabular}

Source: Samples taken from SOEP 2006 (see Wagner et al., 2007).

${ }^{1}$ Subsample of fully employed persons.

${ }^{2}$ Real gross hourly wages (separate deflators for East and West Germany). Wages are trimmed 1 per cent at the top and the bottom to reduce mistakes from extreme outliers.

${ }^{3}$ SOEP question: "How satisfied are you with your life, all things considered?" "0" means completely dissatisfied, "10" means completely satisfied.

${ }^{4}$ Workers in private households with a household head who was an FRG citizen.

${ }^{5}$ Workers in private households with a household head who was a GDR citizen.

${ }^{a}$ significant differences compared to the cohort 1962-66 of the corresponding region at the age of 30 .

b significant differences compared to the corresponding cohort of West Germany.

c significant differences compared to the cohort 1962-66 West at the age of 40.

Bivariate t-test for continuous variables and Pearson's chi square test for 0,1-variables. Significance evaluated at the 5 per cent level. 
Table A2: Socio-economic outcomes of cohorts East and West German male workers, evaluated at the ages of 30 and 40 (means; in brackets SD)

\begin{tabular}{|c|c|c|c|c|}
\hline Cohorts (\# of obs.) & $\begin{array}{c}\text { Education } \\
\text { in years }\end{array}$ & $\begin{array}{c}\text { Wage }^{1,2} \\
\text { in } €\end{array}$ & $\begin{array}{l}\text { Tenure }^{1} \\
\text { in years }\end{array}$ & $\begin{array}{l}\text { Life satis- } \\
\text { faction }^{3} \\
\text { 11s scale }\end{array}$ \\
\hline \multicolumn{5}{|c|}{ at age 30} \\
\hline West Germany ${ }^{4}$ & \multirow{5}{*}{$\begin{array}{l}12.1(2.7) \\
12.2(2.7) \\
12.2(2.6) \\
12.9(2.8)^{\mathrm{a}}\end{array}$} & & & \\
\hline 1957-61 (287 - 394) & & $16.4(4.3)^{\mathrm{a}}$ & $5.9(4.5)$ & $7.1(1.7)$ \\
\hline 1962-66 (316 - 438) & & $15.6(4.0)$ & $5.6(4.3)$ & $7.2(1.6)$ \\
\hline 1967-71 (244 - 339) & & $15.0(4.2)$ & $5.2(4.2)$ & $7.3(1.6)$ \\
\hline $1972-76(118-164)$ & & $15.2(4.5)$ & $5.2(4.1)$ & $7.2(1.6)$ \\
\hline \multicolumn{5}{|l|}{ East Germany ${ }^{5}$} \\
\hline $1962-66(148-212)$ & \multirow{4}{*}{$\begin{array}{l}12.5(2.4) \\
12.4(2.1) \\
12.6(2.2)\end{array}$} & $12.0(3.6)^{b}$ & $4.4(4.1)^{b}$ & $6.5(1.6)^{b}$ \\
\hline 1967-71 (129 - 173) & & $11.9(4.0)^{\mathrm{b}}$ & $5.4(3.9)^{\mathrm{a}}$ & $6.9(1.5)^{\mathrm{ab}}$ \\
\hline 1972-76 (88 - 140) & & $11.3(4.3)^{b}$ & $5.0(3.8)$ & $6.6(1.6)^{b}$ \\
\hline & & 40 & & \\
\hline \multicolumn{5}{|l|}{ West Germany } \\
\hline 1957-61 (237 - 310) & $12.5(2.9)$ & $17.5(5.5)$ & $11.2(7.5)$ & $7.0(1.7)$ \\
\hline 1962-66 (244 - 317) & $12.6(2.8)$ & $18.3(5.9)$ & $10.7(7.1)$ & $6.9(1.7)$ \\
\hline \multicolumn{5}{|l|}{ East Germany } \\
\hline 1962-66 (116 - 157) & $12.6(2.4)$ & $14.0(6.3)^{\mathrm{c}}$ & $9.0(6.0)^{c}$ & $6.3(1.7)^{\mathrm{c}}$ \\
\hline $\begin{array}{l}\text { Total Sample } \\
(1,927 \text { - 2,596) }\end{array}$ & $12.4(2.6)$ & $15.4(6.3)$ & $7.0(5.8)$ & $7.0(1.7)$ \\
\hline
\end{tabular}

Source: Samples taken from SOEP 2006 (see Wagner et al., 2007).

${ }^{1}$ Subsample of fully employed persons.

${ }^{2}$ Real gross hourly wages (separate deflators for East and West Germany). Wages are trimmed 1 per cent at the top and the bottom to reduce mistakes from extreme outliers.

${ }^{3}$ SOEP question: "How satisfied are you with your life, all things considered?" "0" means completely dissatisfied, "10" means completely satisfied.

${ }^{4}$ Workers in private households with a household head who was an FRG citizen.

${ }^{5}$ Workers in private households with a household head who was a GDR citizen.

a significant differences compared to the cohort 1962-66 of the corresponding region at the age of 30.

b significant differences compared to the corresponding cohort of West Germany.

c significant differences compared to the cohort 1962-66 West at the age of 40 .

Bivariate t-test for continuous variables and Pearson's chi square test for 0,1-variables. Significance evaluated at the 5 per cent level. 